Research Article

\title{
The Effect of Corporate Governance Mechanism on Tax Avoidance: Evidence from Manufacturing Industries Listed in the Indonesian Stock Exchange
}

\author{
${ }^{1}$ Dr. Agustina Mappadang, SE. MM, BKP, ${ }^{2}$ Prof. Dr. Tri Widyastuti, SE.Ak, MM, CA, ${ }^{3}$ Agustinus M. \\ Wijaya, SE, SH, MM \\ ${ }^{1,2,3}$ Faculty of Economics and Business, Budi Luhur University, Jakarta
}

\begin{abstract}
This study aims to investigate the influence mechanisms of corporate governance on tax avoidance. The mechanisms of corporate governance measured by the board of commissioners and the institutional ownership. Population in this study are all companies in manufacture companies listed on the Indonesian Stock Exchange during the years 20122016. The samples comprises 87 companies and 435 object with method of this research are using analysis of causality and smart PLS3 was used for analyzing the data and test the hypotheses. The results showed that the corporate governance mechanism negative significant on tax avoidance; board of commissioners have a positive significant on tax avoidance and institutional ownership have a negative significant on tax avoidance.
\end{abstract}

\section{Keywords: Corporate Governance Mechanisms, Tax Avoidance, Institutional Ownership, Board of Commissioners}

\section{Introduction}

The quality of corporate governance is defined as controlled and monitoring by the board of commissioners and the audit committee to ensure the reliability of the financial reporting process (Cohen and Hanno, 2000). The Corporate governance mechanisms relate to how shareholders control / supervise managers to work with the governance system that is created so that it is expected to function as a tool to give investors confidence that they will receive returns on the funds that they have invested. Weaknesses of corporate governance practices are identified as one of the causes of the global financial crisis. The involvement of the board of commissioners and institutional ownership in carrying out its functions influences the level of quality of corporate governance. Bad corporate governance implementation will greatly affect the actions of many tax evasion practices. Tax avoidance is an action taken to reduce the tax burden or corporate tax payable. According to Desai and Dharmapala (2006) tax avoidance is a way to increase the company's profits expected by shareholders by the manager. Tax avoidance actions result in short-term profits but can cause long-term risks to the company due to opportunistic actions taken by managers (Minnick and Noga,2010). Since 1983 Indonesia implemented self assessment system as regulated in law no.6 of 1983 concerning General Provisions and Tax Procedures (KUP) which have undergone a third amendment namely law no. 28 of 2007 concerning KUP. This Self Assessment System is currently applied in tax collection, reporting and payment in Indonesia. Therefore, this system will run well if the community has a high level of voluntary tax compliance.

Relationships corporate governance mechanisms with tax avoidance have been studied by Desai and Dharmapala (2006), Minnick and Noga (2010), Lanis and Richardson (2011) and Armstrong et al. (2012). The research that has been carried out produces a variety of research results, so further research is needed to see the influence of corporate governance mechanisms on tax avoidance, especially companies in Indonesia. This study also adapts to the rules of public companies in Indonesia and the structure of corporate boards in Indonesia that adhere to a two-tier system that is different from the system adopted by countries such as the United States and several European countries, namely one-tier system. This study uses corporate governance mechanisms related to company owners, namely the Board of Commissioners and Institutional Ownership because the board of commissioners and ownership of institutions are full responsible and have authority in making decisions about how to conduct direction, control and supervision of resource management in accordance with company objectives.

Based on the description above, the research question is: "Are corporate governance mechanisms affect on tax avoidance actions?"

\section{Theoretical Principles and Literature Review}

\section{Corporate Governance}

The board of commissioners and the audit committee in hold a supervisory function in corporate governance (Rezaee, 2002: 126). Furthermore Rezaee (2002: 126) notes that corporate governance is seen as an interaction between actors in management functions (ie management), supervisory functions (ie board of commissioners and audit committee), audit functions (ie external auditors and internal auditors), monitoring functions (ie Bapepam, standard makers, regulators), and user functions (ie investors, creditors, other stakeholders) of the governance system of corporation.

According to Fadhilah (2014), there are two mechanisms in overseeing corporate governance, namely internal and external. The internal mechanism is a way to control a 
company using internal structures and processes such as board meetings, general meeting of shareholders, composition of the board of directors, number of independent board members and number of meetings with the board of directors. While the external mechanism is more to the control of the company, ownership structure and market control. The proportion and professionalism of independent commissioners and board of commissioners in the structure of the board of commissioners will provide better supervision and it will limit the chance fraud by management. Institutional ownership shows existence of majority ownership with strong capital and ha more experienced insights from individual owner Institutional ownership will provide a monitoring function is more effective than individual ownership.

Institutional ownership shows the existence of maj ownership with strong capital and more experienced insi from individual ownership. Institutional ownership provide a better monitoring function that is more effer than individual ownership.

\section{Tax avoidance}

Definition of tax avoidance can give different meanings to different people. Hanlon and Heitzman (2010) define that tax avoidance as an explicit tax reduction. According to Xynas (2011) that tax avoidance is an attempt to reduce tax debt that is legal (lawful), while tax evasion (evasion) is an attempt to reduce tax debt that is illegal (unlawful). Siemrod (2004) argues that tax aggressiveness is a more specific activity, which includes transactions whose main purpose is to reduce corporate tax liability. Tax avoidance by a company cannot be separated from the existence of agency theory and stakeholder theory.

The measurement of tax avoidance offered in this study is the Avoidance Tax Rate (ATR). ATR shows how much (in percentage) taxes can be avoided by the company compared to the applicable tax rate. The ATR number can directly indicate the amount of tax avoidance (in percentage) carried out by the company so that ATR can also be said to measure how much the company's income (in percentage) is not taxed compared to the prevailing tax rate. Companies that have a positive ATR number means that the tax rate paid by the company is smaller than the applicable tariff so that it can be said that the company is suspected of tax avoidance while the negative ATR number means the opposite.

Some researcher investigated the affect of corporate governance mechanism on tax avoidance and they found a negative effect on tax avoidance.

\section{Hypotheses}

Based on the theoretical principles and objectives research, the following hypotheses are followed :

H1: The corporate governance mechanism has a significant effect on tax avoidance

H2: The board of commissioners has a siginificant effect on tax avoidance

H3: The institutional ownership has a significant effect on

\section{tax avoidance}

This study developed a model of empirical research based on basic theoretical development and previous studies. The empirical research model describes the relationship between the variables used in this study. The empirical research can be shown as below:

\section{Picture 1.1 Model Penelitian Empirik}

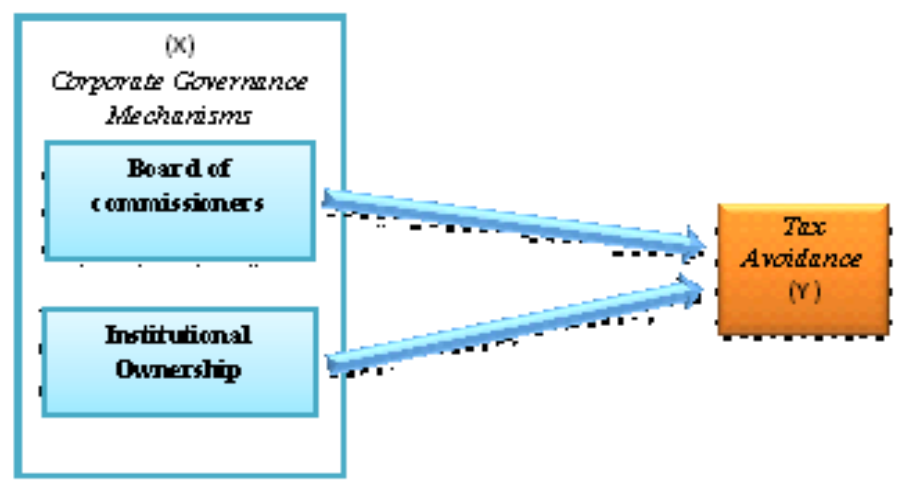

\section{Research Methodology}

This study focused on empirical testing of the model building that was developed based on the empirical research model with the corporate governance mechanism on tax avoidance. This type of research is descriptive causality research with Purposive sampling method and used 435 observations, using regression analysis tools to test hypotheses.

Table 1.1 Operational variable

\begin{tabular}{|c|c|c|c|}
\hline Variable & $\begin{array}{c}\text { Sub } \\
\text { Variable }\end{array}$ & Measurement & $\begin{array}{l}\text { Previous } \\
\text { research }\end{array}$ \\
\hline $\begin{array}{l}\text { Endogen } \\
\text { (Y) } \\
\text { Tax } \\
\text { avoidance }\end{array}$ & $\begin{array}{l}\text { AvoidanceT } \\
\text { ax Rate }\end{array}$ & $\begin{array}{l}\text { Tax avoidance Rate } \\
=\text { Tax rate apply- } \\
\text { effective tax rate. } \\
\text { Applicable tax rate } \\
\text { was } 25 \% \\
\text { ETR = tarif pajak } \\
\text { efektif } \\
\left(\frac{\text { Total Tax Expense it }}{\text { Earning before tax it }}\right)\end{array}$ & $\begin{array}{l}\text { Hanlon, } \\
2010 ; \\
\text { Minnick and } \\
\text { Noga } \\
(2010) ; \text { UU } \\
\text { PPh no. 36, } \\
2008\end{array}$ \\
\hline \multirow[t]{2}{*}{$\begin{array}{l}\text { Eksogen } \\
(\mathbf{X}) \\
\text { Corporate } \\
\text { Governan } \\
\text { ce } \\
\text { Mechanis } \\
\mathrm{m}\end{array}$} & $\begin{array}{l}\text { Board of } \\
\text { Commission } \\
\text { ers }\end{array}$ & $\begin{array}{l}\text { Total number of } \\
\text { company board } \\
\text { members }\end{array}$ & $\begin{array}{l}\text { Lipton and } \\
\text { Lorsch } \\
\text { (1992), } \\
\text { Jensen } \\
\text { (1993), } \\
\text { Yermack } \\
(1996)\end{array}$ \\
\hline & $\begin{array}{l}\text { Institusional } \\
\text { Ownership }\end{array}$ & $\begin{array}{l}\text { Percentage of } \\
\text { institutional stock } \\
\text { ownership held by } \\
\text { the institutional } \\
\text { investors from the } \\
\text { entire share capital } \\
\text { of the company. }\end{array}$ & $\begin{array}{l}\text { Beiner et al., } \\
2004 \text {; Al- } \\
\text { Abbas } \\
\text { (2009); Jiang } \\
\text { and } \\
\text { Andarajan } \\
(2009)\end{array}$ \\
\hline
\end{tabular}


Dr. Agustina Mappadang, SE. MM, BKP et al / The Effect of Corporate Governance Mechanism on Tax Avoidance: Evidence from Manufacturing Industries Listed in the Indonesian Stock Exchange

\section{Empirical Findings}

\section{Deskriptif Statistic}

Table 1.2 represents the variable descriptive statatistics of the data used in this study.

Table 1.2 Results of descriptive statistics of variables

\begin{tabular}{|l|l|l|l|l|}
\hline & Mean & $\begin{array}{l}\text { Standard } \\
\text { Deviation }\end{array}$ & Minimum & Maximum \\
\hline atr & 3.646 & 9.376 & 0.000 & 78.635 \\
\hline ins & 63.275 & 29.529 & 0.000 & 90.000 \\
\hline kom & 4 & 1.626 & 3 & 7 \\
\hline
\end{tabular}

Source : Result of data procesing, 2018

\section{a. Institutional ownership (ins)}

Institutional ownership has a maximum value is 90.00 and a minimum value is 0.00 with an average institutional ownership is 63.275. This result shows that average shares of manufacturing companies listed on the Indonesia Stock Exchange are owned by Institutions, this can be interpreted that manufacturing companies in Indonesia on that period 2012-2016 were more dominated by the institution. This result supports the information submitted by the Indonesia Stock Exchange (IDX) states that the percentage of share ownership for institutional investors is compared with individual investors are 60: 40 ratio.

\section{b. Board of commissioners (kom)}

Results of the data analysis indicate that board of commissioners has a mnimum value is 3 person and maximum value is 7 person with the average number is 4 person. It means that averave number of board of commissioners at the manufacturing industries listed on the Indonesia Stock exchange had 4 commissioners. The board of commissioners has a very important role in the company. The board of commissioners is one of the organs of the company that has the task of carrying out supervision in general or specifically in accordance with the Articles of Association of the company as well as providing advice to the Board of Directors in carrying out company activities.

\section{c. Tax avoidance (atr)}

Results of the data analysis indicate that tax avoidance has a maximum value of 78,635 and a minimum value of 0.00 and the average tax avoidance is 3,646. This result shows that the average manufacturing companies listed on the Indonesia Stock Exchange in the 2012-2016 period had an ATR of $3,646 \%$. This means that manufacturing companies carry out tax avoidance at a rate of $3.6 \%$ less than the normal tax rates applicable in Indonesia.

The classic assumption test will be known the results with SPSS software version 14. Ghozali (2005) reveals that this test consists of three parts :

\section{Picture 1.2 Normality Test}

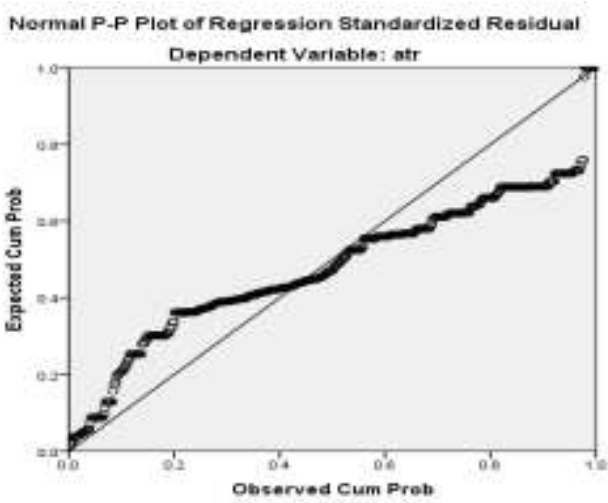

The picture above shows that the data spread around the diagonal line and following the direction of the diagonal line or the normal histogram / graph graph the plot shows a normal distribution pattern, then the regression model meets the assumption of normality.

Picture 1.3 Heterokedasitas Test

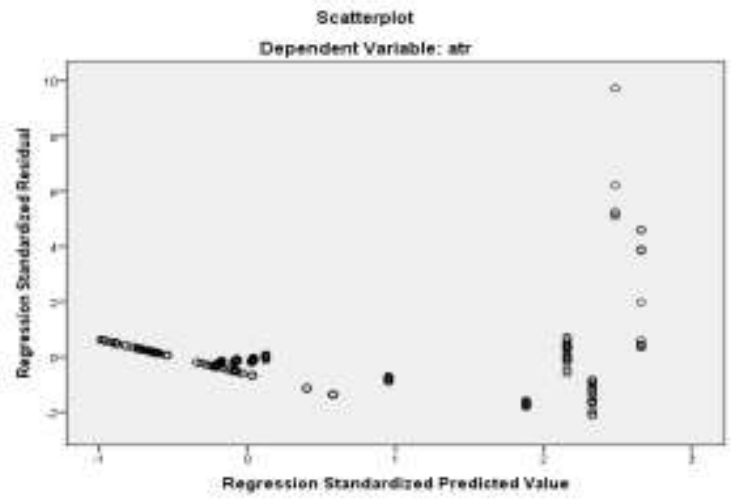

The results showed on the scatter plot graph that the points spread randomly and spread both above and below zero on the $\mathrm{Y}$ axis so it can be concluded that there is no heteroscedasticity in the regression model that be used. Multicollinearity tests can be done to determine the relationship between indicators. To find out whether formative indicators experience multicolliniearity by knowing the VIF value. VIF values between $5-10$ can be said that the indicator occurs multicolliniearity.

Table 1.3 Collinearity Statistic

\begin{tabular}{|c|c|}
\hline \multicolumn{2}{|c|}{ Collinearity Statistics } \\
\hline Tolerance & VIF \\
\hline & \\
.787 & 1.271 \\
.379 & 2.638 \\
.431 & 2.318 \\
\hline
\end{tabular}

Table 1.4 R Square

\begin{tabular}{|c|c|c|c|c|}
\hline Model & $\mathrm{R}$ & $\mathrm{R}$ Square & $\begin{array}{c}\text { Adjusted R } \\
\text { Square }\end{array}$ & $\begin{array}{c}\text { Std. Error of the } \\
\text { Estimate }\end{array}$ \\
\hline 1 & $.785^{\mathrm{a}}$ & .616 & .613 & 5.83207 \\
\hline
\end{tabular}

a. Predictors: (Constant), dkom, ins

b. Dependent Variable: atr 
Dr. Agustina Mappadang, SE. MM, BKP et al / The Effect of Corporate Governance Mechanism on Tax Avoidance: Evidence from Manufacturing Industries Listed in the Indonesian Stock Exchange

Tabel. 1.5 ANOVAa

\begin{tabular}{|c|c|c|c|c|c|}
\hline Model & $\begin{array}{c}\text { Sum of } \\
\text { Squares }\end{array}$ & df & $\begin{array}{c}\text { Mean } \\
\text { Square }\end{array}$ & F & Sig. \\
\hline Regression & 23492.639 & 3 & 7830.880 & 230.231 & $.000^{\mathrm{b}}$ \\
Residual & 14659.642 & 431 & 34.013 & & \\
Total & 38152.281 & 434 & & & \\
\hline
\end{tabular}

a. Dependent Variable: atr

b. Predictors: (Constant), dkom, ins

Table. 1.6. Coefficients ${ }^{\mathrm{a}}$

\begin{tabular}{|c|c|c|c|c|c|}
\hline Model & \multicolumn{2}{|c|}{$\begin{array}{c}\text { Unstandardized } \\
\text { Coefficients }\end{array}$} & $\begin{array}{c}\text { Standardized } \\
\text { Coefficients }\end{array}$ & \multirow{2}{*}{ Sig. } \\
\cline { 2 - 5 } & B & Std. Error & Beta & & \\
\hline (Constant) & 46.175 & 3.571 & & 12.93 & .000 \\
& & & & 1 & \\
& & & & & \\
ins & -.238 & .015 & -.751 & - & .000 \\
& & & & 15.48 & \\
dkom & 1.292 & .281 & .209 & 4.603 & .000 \\
\hline
\end{tabular}

1. Hypothesis test 1 (H1) : Effect of the Corporate Governance Mechanism on Tax Avoidance

The first hypothesis shows that the corporate governance mechanism have a negative effect on tax avoidance. The results of the data show f count of 230,231 with $p$ value of less than 5\%. This shows that the corporate governance mechanism influences tax avoidance. The determination coefficient of 0.616 indicates that tax avoidance can be explained by the corporate governance mechanism is $61.60 \%$ while the remaining $39.4 \%$ is explained by other variables is not included in the model

The results of the study in table 1.2 for the period of 20122016 on manufacturing industry companies that listed on BEI, the figures listed show that the average institutional ownership is $63.27 \%$ and the board of commissioners are 4 people has met the minimum requirements for companieslisted at BEI according with the decision of the Director of the Jakarta Stock Exchange Number: Kep-315 / BEJ / 06/2000.

The mechanism of corporate governance in the manufacturing industry on average is quite effective in carrying out the function. It means controlling and monitoring by the behavior of management in order to act proportionally especially in tax avoidance.

Good corporate governance is a process or system in which the implementation of a company is controlled and supervised to create added value for all stockholders (Desai \& Dharmapala, 2007). Companies that have good governance mechanisms will be directly proportional to the company's compliance in fulfilling its tax obligations (Sartori, 2010). Corporate governance was created for tax management in order to be able to run under applicable law so that companies always comply with tax compliance. Corporate governance ensures that corporate governance in taxation remains within the corridor of tax avoidance that is legal rather than tax evasion that is illegal. The principles of good governance that are supervised and controlled by the governance mechanism will make management more cautious of tax avoidance practices that have bad implications to the company.

Hypothesis test 2 (H2) : Effect of the Board of Commissioners on Tax Avoidance

The results showed that the board of commissioners has a positive effect on tax avoidance as seen from the results of the regression data in table 1.5 and table 1.6 with the direction of a positive coefficient of 1,292 with $t$ stat equal to 4,603 (> 1.96) or significant at $p$ value less than $5 \%$ so hypothesis can be accepted. A significant positive coefficient direction means that the Board of Commissioners allows management to carry out tax avoidance in a legal corridor. The board of commissioners is a representative of the shareholders so as to allow management to carry out tax avoidance measures as long as they are within the corridor of the applicable law. This is related to the interest in maximizing profits which has implications for reducing the tax burden. The results of this study are in line with previous studies from Rego and Wilson (2008).

Hypothesis test 3 (H3) : Effect of the Institutional Ownership on Tax Avoidance

The results showed that the Institutional Ownership has a negative effect on tax avoidance as seen from the results of the regression data in table 1.5 and table 1.6 with the direction of the negative coefficient of -0.238 with t stat 15.484 (> 1.96) or significant at $\mathrm{p}$ value less than $5 \%$. Hypothesis 3 is accepted. Institutional ownership is a large part (more than 5\%) then Individual ownership. Therefore it has ability to monitor and control all management aspect. Institutional ownership does not allow management to commit a tax avoidance which results in company disadvantages for the future. They are commit and compliance to follow the tax law. The results of this study are in line with research from Ngadiman and Christiany (2014); Cornertt et.al (2006).

\section{Conclusions}

This study ought to find the answer to the question whether the corporate governance mechanism affect on tax avoidance. In this regards, the criteria including the number of board commissioners and Institutional ownership were used as corporate governance mechanism. In this research we found from the first hypothesis indicates that the corporate governance mechanism has a positive effect on the level of corporate tax compliance to minimize tax aggressiveness. The board of commissioners has a positive effect on tax avoidance. This means that the board of commissioners as a representation of the interests of shareholders. Therefore they would like to maximize profit-oriented which $t$ allowing tax avoidance by the Directors. The Institutional Ownership has a negative effect on tax avoidance. It means the Institutional ownership as a sophisticated ownership want to follow the rules and comply all the government regulation. Encouragement of the institution to oversee the management 


\section{Dr. Agustina Mappadang, SE. MM, BKP et al / The Effect of Corporate Governance Mechanism on Tax Avoidance: Evidence from Manufacturing Industries Listed in the Indonesian Stock Exchange}

of compliance in carrying out taxation rules so that tax avoidance measures are reduced. They prefer to concern to get advantage for the long term company's future.

This study has limitations because of the limitations of the research sample in the case of many companies listed on the Jakarta Stock Exchange but the annual report was not published on the IDX website and the financial statements were issued in USD so that the limitations in converting to the real Rupiah were limited. Another limitation is that it only displays samples in the manufacturing industry without seeing another industries.

Suggestions for further research that it is better to get more information research from another industries, the research period should be add so it can be known more precisely the impact of long-term research and more variables with different proxies in order to reflect the advantages and disadvantages.

\section{References}

[1] Armstrong, Christopher S., Jennifer L. Blouin, and David F. Larcker. 2012. "The Incentives for Tax Planning". Journal of Accounting and Economics 53: 391-411.

[2] Al-Abbas, M. A, 2009,: "Corporate Governance and Earnings Management: an Empirical Study of The Saudi Market". The Journal of American Academy of Business. Vol. 15. No. 1. Pp. $301-310$.

[3] Beiner, S. et. al. (2004). "Is Board Size An Independent Corporate Governance Mechanism?". Financial Valuation and Risk Management. Working Paper No 89.

[4] Cohen, J. R., dan D. M. Hanno. 2000. Auditors' Consideration of Corporate Governance and Management Control Philosophy in Preplanning and Planning Judgments. Auditing: A Journal of Practice \& Theory 19 (2): pp 133-146.

[5] Cornett, M. M., A. J. Marcus, A. Saunders, dan H. Tehranian. 2006. "Earnings Management, Corporate governance, and True Financial Performance" http://ssrn.com/abstract $=886142$. [diakses pada January 2017].

[6] Desai, M. A., dan D. Dharmapala. 2006. "Corporate tax avoidance and high-powered incentives". Journal of Financial Economics, Vol. 79, No. 1, him: 145-179.

[7] _ 2007. "Taxation and Corporate governance: An Economic Approach" http://dx.doi.org/10.2139/ssrn.983563. [diakses pada Maret 2012].

[8] Fadhilah, Rahmi. 2014. "Pengaruh Good Corporate Governance Terhadap Tax Avoidance" (Studi Empiris pada Perusahaan Manufaktur yang Terdaftar di Bursa Efek Indonesia 2009-2011). Jurnal Akuntansi Universitas Negeri Padang, 2 (1).

[9] Hanlon, M., dan S. Heitnnan. 2010. "A review of tax research". Journal of Accounting and Economics, Vol. 50, No. 2-3, hlm: 127-178.

[10]Jiang, W., and Anandarajan, A., 2009, Shareholder Rights, Corporate Governance and Earnings Quality: The
Influence of Institutional Investors, Managerial Auditing Journal. Vol. 24. No. 8. Pp. $767-791$.

[11] Lanis, R. and G. Richardson. 2011. "Corporate Social Responsibility and Tax Aggressiveness: An Empirical Analysis". J. Account. Public Policy, pp.86-08.

[12] Lipton, M., dan J. W. Lorsch. 1992. "A modest proposal for improved corporate governance". Business Lawyer, Vol. 48, No., hlm: 59-77.

[13] Minnick, K., dan T. Noga. 2010. "Do corporate governance characteristics influence tax management?". Journal of Corporate Finance, Vol. 16, No. 703-718.

[14] Ngadiman dan Christiany, 2014. Pengaruh Leverage, Kepemilikan Institusional dan Ukuran Perusahaan Terhadap Tax avoidance pada Perusahaan Manufaktur di BEI tahun 2010-2012. Jurnal Akuntansi. Vol.XVII, No. 03

[15] Rezaee, Z. 2007. Corporate governance post- Sarbanas Oxley: regulatioms, requirements and integrated processes: John Willey \& Sons, Inc.

[16] Rego, S.O. dan R. Wilson. 2008. "Equity Risk Incentives and Corporate Tax Aggressiveness." Journal of Accounting Research Vol. 50 No.3 June 2012, h. 775810.

[17] Republik Indonesia, 2008. "Undang-Undang Nomor 36 Tahun 2008 Tentang Perubahan keempat Undang-Undang No. 7 Tahun 1983 tentang Pajak Penghasilan".

[18] Sartori, N, 2010. "Corporate governance Dynamics and Tax Compliance" http://ssrn.com/abstract=136195 [diakses pada Maret 2012].

[19] Slemrod, J. 2004. "The Economics of Corporate Tax Selfishness". National Tax Journal, vol. 57, No. 4 December, him: 877-899. Square)". Untuk Penelitian Empiris. Badan Penerbit Fakultas Ekonomi Dan Bisnis UGM, Yogyakarta,

[20] Xynas, L. 2011. "Tax Planning, Avoidance and Evasion in Australia 1970-2010: The Regulatory Responses and Taxpayer Compliance". Revenue Law Journal, Vol. 20, No. 1.

[21] Yermack, D. 1996. "Higher market valuation of companies with a small board of directors". Journal of Financial Economics, Vol. 40, No., hlm: 185-211. 